\title{
IGHG1 wt Allele
}

National Cancer Institute

\section{Source}

National Cancer Institute. IGHG1 wt Allele. NCI Thesaurus. Code C98021.

Human IGHG1 wild-type allele is located in the vicinity of $14 q 32.33$ and is approximately 7 $\mathrm{kb}$ in length. This allele, which encodes Ig gamma-1 chain C region protein, plays a role in immunoglobulin functions. Multiple chromosomal translocations involving this gene are associated with multiple myeloma; these translocations include $t(11 ; 14)(q 13 ; q 32)$ with the CCND1 gene, $t(4 ; 14)(p 16.3 ; q 32.3)$ with the FGFR3 gene, and $t(6 ; 14)(p 25 ; q 32)$ with the IRF4 gene. Another translocation $\mathrm{t}(1 ; 14)(\mathrm{q} 25 ; \mathrm{q} 32)$ of this gene and the LHX4 gene is associated with pre-B acute lymphoblastic leukemia. 